\title{
THE EFFECT OF 17\% ETHYLENEDIAMINETETRA-ACETIC ACID AS A MAIN IRRIGATION ON APICAL ROOT CANAL CLEANLINESS (ex vivo)
}

\author{
Eko Fibryanto*
}

'Departemen Konservasi Gigi, Fakultas Kedokteran Gigi, Universitas Trisakti, Indonesia

Correspondence : Eko Fibryanto, Departemen Konservasi Gigi, Fakultas Kedokteran Gigi, Universitas Trisakti, Indonesia Email : eko.fibryanto@trisakti.ac.id

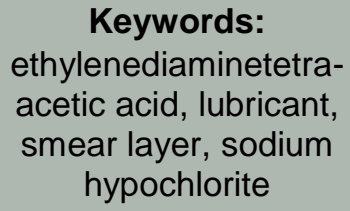

Keywords:

ethylenediaminetetraacetic acid, lubricant, smear layer, sodium hypochlorite

\begin{abstract}
Background: The root canal wall becomes coated with a smear layer predominantly composed of organic and inorganic matter, debris and bacteria during root canal instrumentation. Sodium hypochlorite $(\mathrm{NaOCl})$ and ethylenediaminetetra-acetic acid (EDTA) are effective in removing the smear layer and they perform as lubricants during root canals instrumentation. The aim of this study was to analyze the efficacy of $\mathrm{NaOCl}$ and EDTA as lubricant during root canal preparation on apical third of root-canal wall.

Method: Thirty-two premolars were all decoronated. All samples were randomly divided into 2 groups. All groups were instrumented with rotary instrument from \#10.04 to \#35.04 file. One group was irrigated with 17\% EDTA and the other with $5.25 \% \mathrm{NaOCl}$. Then the teeth were dried, split into 2 halves and evaluated by 2 examiners under scanning electron microscopy (SEM) at the apical third of the root-canal wall at 1000x magnifications. Data was statistically analyzed using Mann-Whitney test.

Result: The result showed that 17\% EDTA produced significantly higher cleanliness on apical third of root-canal wall compared to $5.25 \% \mathrm{NaOCl}$ ( $p<$ 0.05).

Conclusion: EDTA $17 \%$ was able to clean apical third of root-canal wall better than $\mathrm{NaOCl} 5,25 \%$.
\end{abstract}

\section{PENDAHULUAN}

Preparasi saluran akar terdiri atas preparasi mekanis dan kimiawi. Preparasi mekanis dilakukan dengan berbagai jarum/file endodontik dengan ukuran bertingkat yang bertujuan membentuk dan memperbesar saluran akar dengan kekerucutan tertentu. Preparasi kimiawi dilakukan dengan berbagai larutan irigasi untuk membersihkan saluran yang tidak dapat dicapai oleh file. ${ }^{1,2}$ Dinding saluran akar yang terkena aksi dari instrumentasi (manual atau rotary) akan terlapisi oleh lapisan yang didominasi oleh debris dentin yang terkikis disebut smear layer. Pembentukan smear layer terjadi ketika file instrumentasi endodontik pertama digunakan. ${ }^{3}$ Keberadaan smear layer berperan sebagai penghalang fisik dan mencegah penetrasi larutan irigasi, medikamen, siler, dan bahan pengisi saluran akar ke dinding tubula dentin. ${ }^{4}$

Akumulasi debris dentin selama proses pembersihan dan pembentukan saluran akar merupakan hal yang umum terjadi. ${ }^{5}$ Potongan dentin yang terbentuk dari preparasi saluran akar akan menambah hambatan pada saluran akar, jika massa heterogenus organik dan anorganik tidak dikeluarkan dari sistem saluran akar. ${ }^{2}$ Komponen organiknya terdiri dari produk dekomposisi kolagen, prosesus odontoblastik, jaringan pulpa, protein yang terkoagulasi, sel darah, dan pada jaringan pulpa nekrosis terdapat bakteri dan produknya, sedangkan komponen anorganiknya sebagian besar terdiri dari kalsium hidroksiapatit dan 
trikalsium fosfat. ${ }^{3}$ Tidak ada larutan irigasi tunggal yang mampu membuang komponen organik dan anorganik dari smear layer. ${ }^{4}$ Penggunaan larutan $\mathrm{NaOCl}$ dengan konsentrasi $0,5 \%-6,25 \%$ terbukti efektif untuk membuang komponen organik dan EDTA dengan konsentrasi 15\%-17\% untuk membuang komponen anorganik dari smear layer. 4,6

Larutan irigasi selain untuk membuang smear layer, juga berperan sebagai lubrikan selama melakukan instrumentasi. ${ }^{2}$ Kemampuan ini berdasarkan sifat dari larutan irigasi yang dapat membentuk lapisan tipis di antara instrumen dan dinding saluran akar, sehingga mengurangi gaya gesek dari pergerakan instrumen. ${ }^{2}$ Sodium hipoklorit berperan sebagai lubrikan melalui reaksi saponifikasi. Bahan ini bereaksi saat berkontak dengan asam lemak, dan mengubahnya menjadi garam asam lemak (sabun) dan gliserol (alkohol) yang mengurangi tegangan permukaan dari larutan. ${ }^{6}$

Proses instrumentasi yang terus-menerus akan meningkatkan terbentuknya dentin debris yang akan bercampur pada larutan lubrikan dan mengakibatkan terjadinya peningkatan kejenuhan dari larutan. Keberadaan $\mathrm{NaOCl}$ akan menyebabkan material organik mengalami pelarutan, sehingga meningkatkan viskositas dari lubrikan dalam sistem saluran akar. Peningkatan kejenuhan dari campuran larutan lubrikan dengan dentin debris akan meningkatan viskositas oleh pelarutan material organik sehingga menyebabkan larutan irigasi dalam sistem saluran akar menjadi lengket dan kental, dan membentuk yang secara klinis disebut sebagai dentin mud. ${ }^{2}$ Peningkatan kepadatan dari dentin mud dapat mencapai pada kondisi kekentalan yang dapat terdorong secara mekanik oleh adanya efek piston dari instrumentasi, terutama dengan gerakan push-pull filing sehingga dapat menutup foramen apikal, atau lebih lanjut dapat menyebabkan ekstrusi ke daerah periapikal. ${ }^{2,7} \mathrm{Hal}$ ini dapat mengarah kepada reaksi inflamasi dan sakit paska perawatan, atau yang disebut juga "flare-up". ${ }^{7}$

Bahan lubrikan lain yang dianjurkan untuk digunakan adalah EDTA. Bahan ini dalam bentuk pasta meningkatkan kemampuan memotong dari instrument file karena dapat melunakan dinding saluran akar dengan mempengaruhi matriks anorganik dari dentin (seperti hidroksiapatit) dan menciptakan kalsium kompleks stabil yang terdapat pada dentin mud, smear layer, atau deposit kalsifikasi disepanjang dinding saluran akar. Larutan EDTA dapat mengurangi kekerasan mikro dentin karena berkerja pada jaringan yang mengalami kalsifikasi. ${ }^{8} \mathrm{Hal}$ ini dapat membantu untuk mengatasi saluran akar yang kecil atau sempit dan memfasilitasi pembuangan smear layer. $^{9}$ Penggunaan EDTA pasta akan meningkatkan friksi bila digunakan dengan instrumentasi secara rotary, sehingga lebih mungkin menyebabkan terjadinya fraktur pada file. Penggunaan EDTA cair sebagai lubrikan mengurangi friksi pada instrumen, sehingga mengurangi kemungkinan fraktur pada file, namun tidak memiliki efisiensi pemotongan yang sebaik EDTA pasta. ${ }^{8}$ Tujuan penelitian ini adalah menganalisis perbedaan efek larutan $17 \%$ EDTA dan 5,25\% $\mathrm{NaOCl}$ sebagai lubrikan terhadap kebersihan 1/3 apikal selama preparasi saluran akar.

\section{METODE PENELITIAN}

Penelitian ini menggunakan 32 premolar maksila dan mandibula yang sudah diekstraksi untuk keperluan ortodontik yang memiliki akar tunggal dan lurus, setelah pasien menandatangani persetujuan medik. Penelitian ini telah mendapatkan persertujuan etik dari Komisi Etik Penelitian Kesehatan Fakultas Kedokteran Gigi Universitas Trisakti dengan Nomor: 129/S2- 
Sp/KEPK/FKG/7/2018. Gigi tersebut dibersihkan dari plak, kalkulus, dan sisa jaringan periodontal, kemudian direndam dalam larutan salin. Dilakukan dekoronisasi mahkota gigi dengan menggunakan diamond wheel bur (Ref 58 0910D 104 220, Hager \& Meisinger $\mathrm{GmbH}$, Jerman) sehingga menyisakan panjang akar gigi $15 \mathrm{~mm}$. Panjang kerja ditentukan dengan mengurangi $1 \mathrm{~mm}$ dari panjang akar sehingga didapatkan panjang kerja $14 \mathrm{~mm}$.

Sampel dibagi menjadi 2 kelompok, masingmasing kelompok terdiri atas 16 sampel. Kelompok 1 adalah saluran akar yang diirigasi $\mathrm{NaOCI} 5,25 \%$ (Chloraxid 5.25\%, Cerkamed, Polandia) selama instrumentasi. Kelompok 2 adalah saluran akar yang diirigasi EDTA 17\% (Endo-solution, Cerkamed, Polandia) selama instrumentasi. Larutan irigasi dimasukkan ke dalam saluran akar menggunakan syringe dan jarum irigasi side-vented dengan ukuran 30 gauge (CK Endo, Korea) sebanyak $2 \mathrm{~mL}$ selama 30 detik untuk setiap aplikasi.

Seluruh sampel dari tiap kelompok diinstrumentasi menggunakan rotary instrument motor VDW Silver (VDW, Jerman) dan file Mtwo \#10.04 dengan teknik single length sepanjang kerja dengan gerakan in-and-out sebanyak tiga hingga lima gerakan selama 10 detik. Kecepatan dan torsi dari mesin VDW Silver disesuaikan dengan petunjuk pabrik yaitu kecepatan $280 \mathrm{rpm}$ dan torsi $120 \mathrm{~g} / \mathrm{cm}$. Setelah itu, saluran akar diirigasi sesuai dengan kelompoknya dan dipreparasi lebih lanjut mengunakan file Mtwo \#15.05, \#20.06, \#25.06, \#30.05, hingga \#35.04 (VDW, Jerman) secara berurutan dengan teknik single length. Setiap pergantian file saluran akar selalu diirigasi. Pada tahap akhir, saluran akar diirigasi dengan akuades sebanyak $2 \mathrm{~mL}$, lalu dikeringkan dengan paper point \#35 (Gapadent, P.R.China).

Selanjutnya sampel ditandai pada permukaan luar akar gigi dengan menggunakan fissure bur (Komet, USA) secara paralel pada bagian bukal dan lingual. Selanjutnya, akar dibelah dengan menggunakan chisel dan mallet (Virco, Inggris). Potongan sampel gigi diletakkan pada piringan logam dan difiksasi serta dilapis dengan emas menggunakan alat pelapis ion sputter coater (MCM-100, Sec, Korea) selama 2 menit. Setelah itu, sampel diamati dengan Scanning Electron Microscope (SEM) (SNE4500M, Sec, korea). Pengamatan dilakukan pada pembesaran 1.000x dan diamati oleh 2 pengamat yang berbeda.

Kebersihan dinding saluran akar dinilai dengan parameter sebagai berikut: skor 1: tubula dentin terbuka sempurna dan tidak ditemukan smear layer; skor 2: lebih dari 50\% tubula dentin yang terbuka; skor 3 : kurang dari $50 \%$ tubula dentin yang terbuka; skor 4 : lebih dari $75 \%$ tubula dentin tertutup smear layer. ${ }^{9}$ Penilaian skor dilakukan pada foto elektromikrograf SEM. Nilai intra dan inter agreement dianalisis dengan Cohen Kappa. Hasil penilaian dianalisis dengan uji Mann-Whitney untuk membedakan kebersihan masing-masing kelompok. Tingkat kemaknaan penelitian ini adalah $0,05(p \leq 0,05)$.

\section{HASIL PENELITIAN}

Nilai intra agreement Cohen Kappa adalah sangat kuat (1). Data juga dinilai oleh 2 orang pemeriksa (inter agreement) dengan nilai kesepakatan Cohen's Kappa adalah kuat $(0,8)$. Hasil pengamatan pada kelompok EDTA 17\% memperlihatkan bahwa nilai skor 2 paling banyak ditemui, yaitu: lebih dari $50 \%$ tubula dentin yang terbuka (Gambar 1A). Hasil pengamatan pada kelompok $\mathrm{NaOCl} 5,25 \%$ adalah hampir seluruhnya mendapatkan skor 4 , yaitu: lebih dari $75 \%$ tubula dentin tertutup smear layer (Gambar 1B).

Analisis uji Mann-Whitney menunjukkan bahwa ada perbedaan efek larutan EDTA 17\% dan $\mathrm{NaOCl} 5,25 \%$ sebagai lubrikan saat intrumentasi 
terhadap kebersihan 1/3 apikal dinding saluran akar secara bermakna $(p \leq 0,05)$. Hasil analisis terlihat pada Tabel 1. Hasil penelitian ini memperlihatkan bahwa larutan EDTA $17 \%$ lebih baik dalam membersihkan dinding saluran akar dibandingkan larutan $\mathrm{NaOCl} 5,25 \%$ jika digunakan sebagai larutan diantara instrumentasi.

(a)

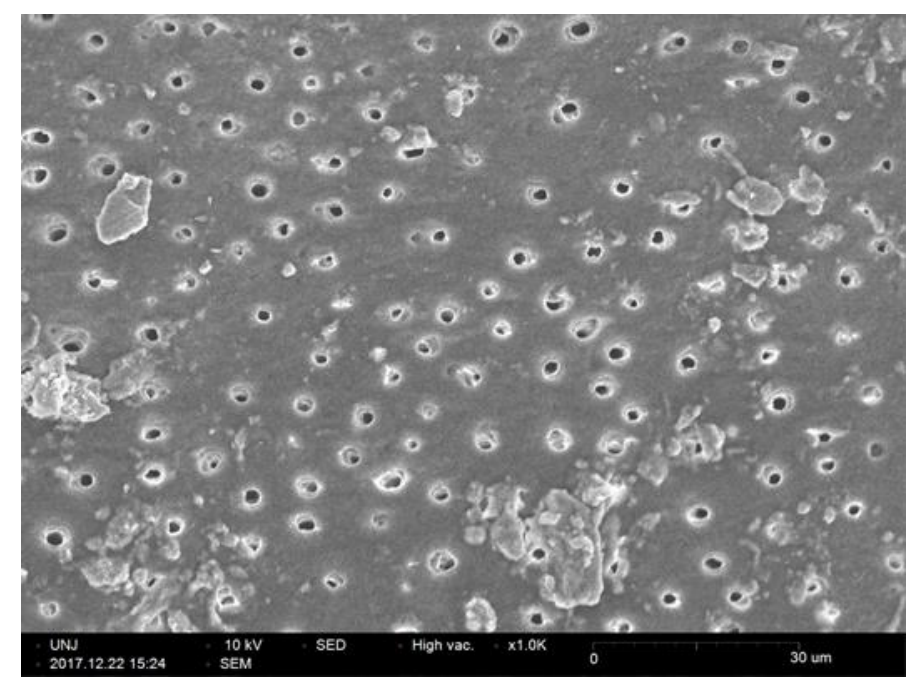

(b)

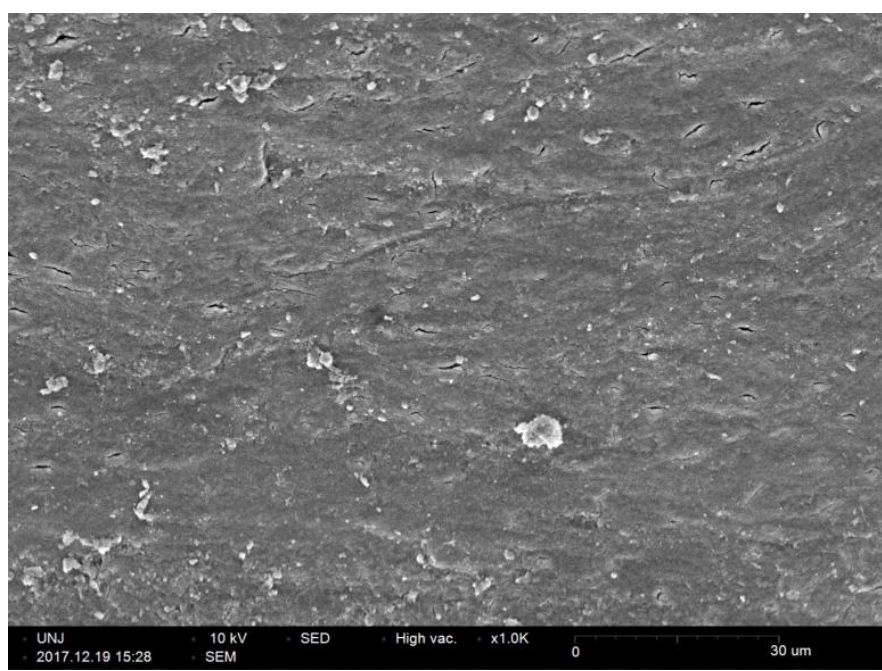

Gambar 1. Electromikrograf SEM (a) Struktur dentin setelah terpapar larutan EDTA 17\% (Skor 2); (b) Struktur dentin setelah terpapar larutan $\mathrm{NaOCl} 5,25 \%$ (Skor 4).

Tabel 1. Skor dan nilai kemaknaan kebersihan dinding $1 / 3$ apikal saluran akar dengan pemeriksaan SEM

\begin{tabular}{llcc}
\hline \multicolumn{1}{c}{ Kelompok } & $\mathrm{N}$ & Median (min-max) & $\mathrm{P}$ \\
\hline EDTA $17 \%$ & 16 & $2 \pm(2-4)$ & $0,001^{*}$ \\
$\mathrm{NaOCl} 5,25 \%$ & 16 & $4 \pm(2-4)$ & \\
\hline
\end{tabular}

* Mann-Whitney dengan $\mathrm{p} \leq 0,05$ 


\section{DISKUSI}

$\mathrm{NaOCl}$ berperan sebagai lubrikan dengan cara terjadinya reaksi saponifikasi, yaitu degradasi lemak menjadi gliserol (alkohol) dan sabun (garam asam lemak). ${ }^{10,11}$ Pembentukan sabun ini selain mengurangi gaya gesek dari instrumen karena membuat permukaan dentin menjadi licin, juga mengurangi tegangan permukaan dari larutan. ${ }^{11}$ EDTA berperan sebagai lubrikan dengan cara mengambil ion kalsium dari hidroksiapatit dentin. Terjadi demineralisasi pada dentin yang membuat kekerasan mikro dentin berkurang dan dentin menjadi lunak, sehingga instrumentasi dinding saluran akar menjadi lebih mudah dan cepat. ${ }^{8}$ Kedua larutan ini memiliki fungsi yang sama sebagai larutan irigasi, namun memiliki cara dan sifat yang berbeda dalam membersihkan saluran akar terutama dinding saluran akar.

Kebersihan dinding saluran akar pada sepertiga apikal saluran akar merupakan bagian yang paling sulit dibersihkan dibandingkan sepertiga tengah dan koronal. ${ }^{12}$ Kebersihan pada bagian apikal sulit dicapai karena ruangan yang terbatas, permeabilitas yang rendah, dan konfigurasi anatomi yang komplek. Teknik irigasi konvensional cukup baik dalam membersihkan saluran akar bagian koronal namun kurang efektif pada bagian apikal. ${ }^{13}$ Udara yang terjebak pada bagian apikal membuat larutan irigasi tidak dapat mencapai bagian apikal sehingga pembersihan yang optimal sulit didapat. ${ }^{14}$ Penelitian ini menggunakan bagian sepertiga apikal sebagai tolak ukur untuk menilai kebersihan dinding saluran akar.

Hasil penelitian ini menunjukkan bahwa penggunaan larutan EDTA 17\% sebagai lubrikan selama instrumentasi saluran akar lebih mampu membersihkan $1 / 3$ apikal dinding saluran akar daripada $\mathrm{NaOCl} 5,25 \%$. Hasil yang lebih baik pada penggunaan EDTA disebabkan oleh kemampuan
EDTA untuk menghilangkan bagian anorganik dan sebagai bahan kelasi yang mampu untuk mengikat ion kalsium dan melarutkannya. ${ }^{6}$ Komposisi dari smear layer sebagian besar terdiri dari bagian anorganik seperti kalsium hidroksiapatit dan trikalsium fosfat. $^{3}$ Berdasarkan sifat $\mathrm{NaOCl}$, seyogyanya larutan ini lebih mampu membersihkan dinding dentin saluran akar karena sifatnya sebagai pelarut jaringan nekrotik dan vital serta reaksi saponikasi yang dapat menurunkan tegangan permukaan. Menurut literatur, $\mathrm{NaOCl}$ bahkan mampu berpenetrasi hingga $300 \mu \mathrm{m}$ ke dalam dentin, ${ }^{15}$ tetapi bila smear layer tidak dihilangkan terlebih dahulu dari dinding saluran akar maka $\mathrm{NaOCl}$ tidak efektif dalam membersihkan (Gambar 1b), sebaliknya bila dinding dentin telah diirigasi sebelumnya dengan EDTA, maka $\mathrm{NaOCl}$ akan bekerja lebih efektif.

Hasil penelitian ini sejalan dengan penelitian sebelumnya yang menyatakan bahwa penggunaan EDTA disetiap pergantian file memberikan tingkat kebersihan yang lebih baik dibandingkan penggunaan EDTA sebagai irigasi akhir setelah selesai dilakukan instrumentasi. ${ }^{3}$ Penggunaan larutan EDTA selama instrumentasi juga memberikan kondisi kebersihan dinding saluran akar yang lebih bersih terhadap smear layer. ${ }^{9}$

Penggunaan $\mathrm{NaOCl}$ sebagai larutan irigasi di antara pergantian instrumentasi file endodontik selain kurang dapat membuang smear layer jika dibandingkan dengan EDTA, dapat menyebabkan komplikasi bila terjadi ekstrusi melalui foramen apikalis atau secara tidak sengaja mengenai oral mukosa yang dapat menimbulkan reaksi alergi yang berbahaya meskipun pada konsentrasi $\mathrm{NaOCl}$ 0,5\%. ${ }^{16,17}$ Tingkat keparahan komplikasi bertambah sesuai dengan konsentrasi $\mathrm{NaOCl}$ yang digunakan. Komplikasi ini dapat terjadi pada foramen apikal 
yang besar atau pada apikal konstriksi yang rusak akibat instrumentasi saluran akar. ${ }^{16}$

Penggunaan EDTA sebagai larutan diantara pergantian file endodontik akan mengurangi kecelakaan yang diakibatkan oleh ekstrusi $\mathrm{NaOCl}$. Biokompabilitas dari EDTA sangat baik. Ekstrusi EDTA melalui foramen apikal ke jaringan periapikal tidak menunjukan adanya kerusakan jarigan setelah 14 hari. Peletakan bahan EDTA setelah dilakukan pulpotomi juga tidak menimbulkan nekrosis pulpa setelah 28 hari. Tidak ada iritasi atau kerusakan jaringan periapikal di 200 kasus pada penggunaan EDTA sebagai irigasi. ${ }^{18}$

Kebersihan dinding dentin saluran akar dipengaruhi oleh efektifitas larutan irigasi yang memiliki kemampuan melarutkan komponen organik dan anorganik sehingga mempengaruhi struktur dentin, seperti: kekerasan mikro, permeabilitas dan solubilitas. Larutan $\mathrm{NaOCl}$ dan EDTA mampu menurunkan kekerasan mikro dentin, namun memiliki kemampuan solubilitas yang berbeda di sepertiga apikal. ${ }^{19}$

Instrumentasi yang dilakukan pada penelitian ini menggunakan sistem Mtwo. Teknik yang digunakan adalah teknik single length yang artinya semua file digunakan sesuai panjang kerja dari awal hingga akhir. Potongan melintang dari file ini membentuk huruf " $S$ " dengan dua sisi pemotong dapat memotong dentin secara efektif dan memiliki ujung file yang tumpul (non-cutting tip). ${ }^{20,21}$ Jarak pitch yang bertambah dari ujung file hingga ke pangkal mengurangi hambatan pada rotasi file dan terdorongnya debri ke apikal, sehingga berdampak pada lebih sedikitnya penumpukan debris pada sepertiga apikal saluran akar bila dibandingkan dengan file lainnya. ${ }^{21}$

Preparasi apikal saluran akar hingga 0,30 $\mathrm{mm}$ efektif untuk pembersihan debris dan smear layer pada bagian apikal. Suatu penelitian menganjurkan ukuran apikal yang besar untuk membersihkan bagian apikal, meskipun tidak dapat diterapkan dalam setiap kasus. ${ }^{22}$ Preparasi apikal premolar maksila dengan 2 saluran akar dan premolar mandibula dengan diameter ukuran file 0,3 mm mampu membersihkan dinding saluran akar hingga $75 \%$. Bila diperbesar hingga $0,4 \mathrm{~mm}$ mampu membersihkan hingga 96\%. Untuk premolar maksila dengan satu saluran akar, pembesaran apikal hingga diameter 0,40 mm, efektif membersihkan saluran akar hingga $63 \% .{ }^{23}$ Berdasarkan panduan tersebut, maka preparasi pada penelitian ini juga dilakukan hingga diameter apikal 0,35 mm.

Pengamatan sampel dipilih dilakukan menggunakan Scanning Electron Microscopy (SEM) karena memiliki pembesaran dari 50x hingga lebih dari 10.000x. ${ }^{24}$ Pembesaran yang umum digunakan untuk mengamati dinding dentin sekitar 500x hingga 1500x. ${ }^{9}$ Gambaran yang dihasilkan SEM berupa gambaran hitam-putih atau tidak berwarna, sehingga warna dari dentin dengan ketinggian yang bervariasi tidak mempengaruhi pengambilan fokus gambar. Hal ini merupakan keterbatasan bila menggunakan mikroskop stereo. ${ }^{24}$

\section{KESIMPULAN}

Berdasarkan penelitian ini dapat disimpulkan bahwa larutan EDTA 17\% sebagai lubrikan mampu membersihkan sepertiga apikal dinding saluran akar lebih baik daripada larutan $\mathrm{NaOCI} 5,25 \%$ saat digunakan sebagai larutan irigasi utama.

\section{DAFTAR PUSTAKA}

1. Peter OA, Noblett WC. Cleaning and Shaping. In: Torabinejad M, Walton RE, Fouad AF, eds. Endodontics Priciples and Practice. 5th ed. Elsevier; 2015:274-279.

2. Gulabivala $\mathrm{K}, \mathrm{Ng} \mathrm{Y}$-L. Nonsurgical Root Canal Treatment. In: Gulabivala K, Ng Y-L, eds. 
Endodontics. 4th ed. Mosby Elsevier; 2014:174-212.

3. Silveira LFM, Silveira CF, Martos J, de Castro LAS. Evaluation of the Different Irrigation Regimens with Sodium Hypochlorite and EDTA in Removing the Smear Layer during Root Canal Preparation. J Microsc Ultrastruct. 2013;1(1-2):51-56.

4. Arslan D, Guneser MB, Dincer AN, Kustarci A, Er K, Siso SH. Comparison of Smear Layer Removal Ability of QMix with Different Activation Techniques. J Endod. 2016;42(8):1279-1285.

5. Arias-Moliz MT, Morago A, Ordinola-Zapata R, Ferrer-Luque CM, Ruiz-Linares M, Baca P. Effects of Dentin Debris on the Antimicrobial Properties of Sodium Hypochlorite and Etidronic Acid. J Endod. 2016;42(5):771-775.

6. Peters OA, Peters $\mathrm{Cl}$, Basrani B. Cleaning and Shaping the Root Canal System. In: Hargreaves KM, Berman LH, eds. Cohen's Pathways of The Pulp. 11th ed. St.Louis: Elsevier; 2016:209-257.

7. Kustarci A, Altunbas D, Akpinar KE. Comparative Study of Apically Extruded Debris Using One Manual and Two Rotary Instrumentation Techniques for Endodontic Retreatment. J Dent Sci. 2012;7(1):1-6.

8. Shantiaee Y, Dianat O, Sharifi F, Nahvi G, Ahari GK. The Impact of Three Different Canal Lubricants on Fracture, Deformity and Metal Slivering of ProtTaper Rotary Instruments. Iran Endod J. 2014;9(2):127-130.

9. Chen G, Chang YC. Effect of Liquid- and PasteType EDTA on Smear-Layer Removal during Root-Canal Instrumentation. J Dent Sci. $2011 ; 6(1): 41-47$.

10. Al-Zahrani M, Al-Zahrani AG. Sodium Hypochlorite Accident in Endodontics: An
Update Review. Int J Dent Oral Health. 2016;2(2):1-4.

11. Kutty SKN, Lekshmi MS, Mohan EA, Isaac L. Pulp Tissue Dissolution in Endodontics - A Review. Int J Applied Dent Sci. 2017;3(2):193196.

12. Violich DR, Chandler NP. The Smear Layer in Endodontics - A Review. Int Endod J. 2010;43(1):2-15.

13. Pereira ESJ, Peixoto IFC, Nakagawa RKL, Buono VTL, Bahia MGA. Cleaning the Apical Third of Curved Canals After Different Irrigation Protocols. Braz Dent J. 2012;23(4):351-356.

14. Peeters HH, Iskandar B, Suardita K, Suharto D. Visualization of Removal of Trapped Air from the Apical Region of the Straight Root Canal Models Generating 2-phase Intermittent Counter Flow during Ultrasonically Activated Irrigation. J Endod. 2014;40(6):857-861.

15. Wang Z, Maezono H, Shen Y, Haapasalo M. Evaluation of Root Canal Dentin Erosion after Different Irrigation Methods Using Energydispersive X-ray Spectroscopy. J Endod. 2016; 42(12):1834-1839.

16. Faras $F$, Abo-Alhassan F, Sadeq A, Burezq $H$. Complication of Improper Management of Sodium Hypochlorite Accident during Root Canal Treatment. J Int Soc Prev Community Dent. 2016;6(5):493-496.

17. Bosch-Aranda ML, Canalda-Sahli C, Figueiredo R, Guy-Escoda C. Complications Following an Accidental Sodium Hypochlorite Extrusion: A Report of Two Cases. J Clin Exp Dent. 2012;4(3):e194-e198.

18. Mohammadi Z, Shalavi S, Jafarzadeh $H$. Ethylenediaminetetraacetic Acid in Endodontics. Eur J Dent. 2013;7(1):S135S142.

19. Aslantas EE, Buzoglu HD, Altundasar E, Serper A. Effect of EDTA, Sodium Hypochlorite, 
and Chlorhexidine Gluconate with or without Surface Modifiers on Dentin Microhardness. J Endod. 2014;40(6):876-879.

20. Hamze F, Honardar K, Nazarimoghadam K. Comparison of Two Canal Preparation Techniques Using Mtwo Rotary Instruments. Iran Endod J. 2011;6(4):150-154.

21. Krishna V, Sujatha, Jayalakshmi, et al. Comparison of the Cleaning Effectiveness of Mtwo \& Protaper Next Rotary System in Permanent Molar Root Canal: An in vitro Study. Int J Applied Dent Sci. 2016;2(2):19-23.
22. Aminoshariae A, Kulild J. Master Apical File Size-Smaller or Larger: A Systematic Review of Microbial Reduction. Int Endod J. 2015;48(11):1007-1022.

23. Hecker H, Bartha $T$, Lost C, Weiger R. Determination the Apical Preparation Size in Premolars: Part III. Oral Surg Oral Med Oral Pathol Oral Radiol Endod. 2010;110(1):118124.

24. Paradella TC, Bottino MA. Scanning Electron Microscopy in Modern Dentistry Research. Braz Dent Sci. 2012;15(2): 43-48. 